\title{
PEMBERDAYAAN MASYARAKAT DI DESTINASI WISATA TEBING KERATON KAMPUNG CIHAREGEM PUNCAK DESA CIBURIAL KABUPATEN BANDUNG
}

\author{
Andhika Chandra Lesmana ${ }^{1}$ \\ STIEPAR YAPARI, Bandung. \\ andhika.lesmana87@yahoo.com \\ Emron Edison ${ }^{2}$ \\ STIEPAR YAPARI, Bandung, \\ emron.bdg@gmail.com \\ Antika Dara $^{3}$ \\ Alumni STIEPAR YAPARI, Bandung, \\ dara.tika@yahoo.com
}

\begin{abstract}
ABSTRAK
Tebing Keraton merupakan destinasi wisata baru di Jawa Barat, yang terletak di Kabupaten Bandung. Namun kurangnya pemberdayaan masyarakat yang berbentuk aktifitas di sekitar kawasan wisata, yaitu di kampung ciharegem puncak, dapat terlihat dari kurangnya pengetahuan warga tentang kepariwisataan. Masyarakat yang telah terlibat dalam kegiatan pariwisata di sekitar Tebing Keraton pun terlihat kurang mengetahui tentang kepariwisataan. Sehingga masih sedikit masyarakat yang merasakan manfaat adanya tempat wisata di daerah mereka. Dengan melihat potensi sumber daya alam, dan kondisi sektor usaha yang ada, maka kawasan ini dapat menjadi destinasi wisata yang menarik. Penelitian ini menggunakan metode penelitian deskriptif. Dengan digunakan metode penelitian ini dapat diperoleh gambaran atau lukisan secara sistematis, aktual dan akurat mengenai fakta-fakta, sifat-sifat, serta hubungan antara fenomena yang diteliti, yaitu tentang potensi-potensi dan sektor usaha yang ada di sekitar kawasan wisata Tebing Keraton khususnya di Kampung Ciharegem Puncak, yang menjadi narasumber dalam penelitian ini adalah Pemerintah Setempat dan masyarakat di sekitar Kampung Ciharegem Puncak. Dari hasil penelitian ini didapatkan suatu kesimpulan berupa kegiatan atau aktifitas masyarakat sebagai implementasi pemberdayaan yang terdiri darienabling, empowering, Protecting, supporting, dan foresting.
\end{abstract}

Kata Kunci:Pemberdayaan Masyarakat, Destinasi Wisata Tebing Keraton, Kampung Ciharegem Puncak. 


\title{
COMMUNITY EMPOWERMENT INTOURISM DESTINASITION TEBING KERATON KAMPUNG CIHAREGEM PUNCAK DESA CIBURIAL KABUPATEN BANDUNG
}

\begin{abstract}
Tebing Keraton is a new tourist destination in West Java, which is located in Bandung regency. However, the lack of communities empowerment around the tourist area, namely in the Ciharegem Puncak village, could be seen from the lack of local people's knowledge of about the tourism itself. People who had been involved in the tourism activities around Tebing Keraton showed that they were lack of knowledge about tourism. As a result, there were still a few people who got the benefits from the tourist attractions in their area. By looking at the potential which was owned bythe potential of natural resources, and the existing condition of the business sector, then this area can be an attractive tourism destination. This research used descriptive method. This research presented a systematic picture, timely and reliable facts, nature, and the relationship between the phenomena studied, which was about the potentials and the business sector in the tourist area around Tebing Keraton especially in Ciharegem Puncak village. The participants in this research were the Local Government and the communities around Ciharegem Puncak village. Of the reasults of this research, obtained conclusion in form of activities of the community as the implementation of empowerment, wich consists of enabling, empowering, protecting, supporting and foresting.
\end{abstract}

Keywords: Community Empowerment, Tebing Keraton Tourism Destination, Ciharegem Puncak Village.

\section{PENDAHULUAN}

Sektor pariwisata merupakan sumber devisa, dan telah mengambil peran penting dalam membangun perekonomian suatu daerah. Kini, masing-masing pemerintah daerah sudah berbenah diri untuk menjadikan daerahnya sebagai tujuan wisata. Bandung utara salah satunya merupakan destinasi wisata alam dengan panorama yang indah, seperti halnya di Tebing Keraton.

Tebing Keraton merupakan lokasi wisata alam yang berada di Kampung Ciharegem Puncak, Kecamatan Cimenyan, Kabupaten Bandung. Meskipun merupakan wisata baru, tetapi sudah dapat dikatagorikan sebagai destinasi wisata, karena telah memiliki akses jalan, tersedianya pemondokan, dan fasilitas penunjang lainnya. Namun bagaimanapun juga, kehadiran sebuah destinasi wisata harus dapat memberdayakan masyarakat dan meningkatkan perekonomian daerah sekitarnya. Dalam hal ini, masyarakat di desa Ciharegeum Puncak telah merasakan mafaatnya, dan ikut berpartisipasi dengan membentuk kelompok usaha 
kecil menengah secara mandiri, seperti pemondokan sederhana.. Pemondokan ini dibuat untuk memfasilitasi wisatawan yang datang pada dini hari atau waktu subuh untuk menyaksikan keindahan matahari terbit dari Tebing Keraton.

Selain itu, sudah ada juga masyarakat yang membuat kerajinan tangan seperti gantungan kunci yang bertuliskan Tebing Keraton untuk dijadikan souvenir. Namun demikian, penulis juga menyoroti lahan parkir yang ada disana, meskipun saat ini Tebing Keraton sudah dikelola oleh Tahura Djuanda (Taman Hutan Raya Ir. Djuanda), tetapi Tahura hanya berfokus pada pengembangan dan pemugaran destinasi wisatanya saja, sehingga lahan parkir dikelola oleh masyarakat. Selain itu, pedagang di sekitarnya melayani dengan ala masingmasing, ini perlu adanya sosialisasi dan pembinaan agar tuan rumah (masyarakat sekitarnya) dapat menyajikan dan mengelolanya secara profesional, sehingga destinasi menjadi daya tarik yang berkesan indah. Ini semua perlu konsep pemberdayaan masyarakat terpadu, sehingga dapat menjadi perhatian para wisata berkelas dunia, potensi itu ada, seperti halnya yang dilakukan di desa adat Panglipuran, Bali. Oleh karena itu peneliti tertarik untuk mengkaji pemberdayaan masyarakat yang terkonsep dengan baik sesuai dengan tujuan Pariwisata.

\section{Pariwisata}

Istilah pariwisata terlahir dari bahasa Sansekerta yang komponenkomponennya terdiri dari, Pari: penuh, lengkap. Berkeliling, Wis (man): rumah, property, kampung, komunitas, Ata: pergi terus-menerus, mengembara. Yang bila dirangkai menjadi satu kata melahirkan istilah pariwisata, berarti: terus pergi secara lengkap meninggalkan rumah (kampung) berkeliling terus-menerus. Dalam operasionalnya istilah pariwisata sebagai pengganti istilah asing tourism atau travel diberi makna oleh pemerintah Indonesia: "mereka yang meninggalkan rumah untuk mengadakan perjalanan tanpa mencari nafkah ditempat-tempat yang dikunjungi sambil menikmati kunjungan mereka" (Nyoman S. Pendit, 2006)

Menurut Undang Undang No.10/2009 tentang kepariwisataan, yang dimaksud pariwisata adalah berbagai fasilitas serta layanan yang di sediakan masyarakat, pengusaha, Pemerintah dan Pemerintah Daerah. Dan, menurut Richard Shite dalam Marpaung dan Bahar, (2000) menjelaskan bahwa: "Pariwisata adalah suatu perjalanan yang dilakukan orang untuk sementara waktu, yang diselenggarakan dari suatu tempat ke tempat lain meninggalkan tempatnya semula,dengan suatu perencanaan dan dengan maksud bukan untuk berusaha atau mencari nafkah di tempat yang dikunjungi, tetapi semata-mata untuk menikmati kegiatan pertamsyaan dan rekreasi atau untuk memenuhi keinginan yang beraneka ragam."

Richardson dan fluker (2004) menjelaskan, "Tourism comprises the activities or persons,travelling to and staying in place outside their usual environment for not more than one consecutive year for leisure,bussines and other purpose"atau "Pariwisata terdiri dari kegiatan atau seseorang yang melakukan perjalanan ke dan tinggal di luar lingkungan mereka untuk waktu yang tidak lebih dari satu tahun berturut-turut untuk bersantai, bisnis dan tujuan lainnya.

Pariwisata adalah fenomena kemasyarakatan yang menyangkut manusia, masyarakat, kelompok, organisasi, kebudayaan, dan sebagainya, yang merupakan 
objek kajian sosiologi. Hal ini terkait dengan kenyataan bahwa pariwisata pada awalny lebih dipandang sebagai kegiatan ekonomi dan tujuan utama pengembangan pariwisata adalah untuk mendapatkan keuntungan ekonomi, baik bagi masyarakat maupun daerah atau negara.

Disamping karena menyangkut manusia dan masyarakat, manusia dengan berbagai aspek merupakan objek studi sosiologi, analisis sosiologi terhadap pariwisata sangat penting dilakukan dengan mengingat berbagai alasan, salah satunya adalah, pariwisata telah menjadi aktivitas sosial ekonomi dominan dewasa ini, bahkan disebut-sebut sebagai "Industri terbesar sejak akhir abad 20" (WTO, 1998) yang juga menyangkut "pergerakan barang, jasa dan manusia dalam skala terbesar yang pernah terjadi dalam sejarah manusia". Selain itu pariwisata bukanlan sebuah kegiatan yang beroperasi dalam ruang hampa. Pariwisata sangat terkait dengan masalah sosial, politik, ekonomi, keamanan, ketertiban, keramahtamahan, kebudayaan, kesehatan, dan sebagainya, termasuk industri sosial yang mengaturnya.Pariwisata juga bersifat sangat dinamis, sehingga setiap saat memerlukan analisis atau kajian lebih tajam. Sebagai suatu aktifitas yang dinamis, pariwisata memerlukan kajian terus menerus (termasuk dari aspek sosial budaya), yang juga harus dinamis, sehingga pembangunan pariwisata bisa memberikan manfaat bagi kehidupn manusia, khususnya masyarakat local.

Pariwisata selalu mempertemukan dua atau lebih kebudayaan yang berbeda, yang mempunyai perbedaan dalam norma, nilai, kepercayaan, kebiasaan dan sebagainya. Sehingga menghasilkan berbagai proses alkulturasi, dominasi, asilmilasi, adopsi, adaptasi, dan seterusnya dalam kaitan hubungan antar budaya, yang tentu saja merupakan salah satu isu sentral dalam sosiologi. Dewasa ini pariwisata sudah hampir menyentuh semua masyarakat dunia, sampai masyarakat terpencil kini sudah dirambah pariwisata dengan berbagai derajat pengaruh.

\section{Jenis - Jenis Pariwisata}

Jenis-jenis pariwisata menurut James J. Spillane (1987) berdasarkan motif tujuan perjalanan dapat dibedakan menjadi beberapa jenis pariwisata khusus, yaitu:

1. Pariwisata untuk menikmati perjalanan (Pleasure Tourism).

Jenis pariwisata ini dilakukan oleh orang-orang yang meninggalkan tempat tinggalnya untuk berlibur, mencari udara segar, memenuhi kehendak ingintahunya, mengendorkan ketegangan syaraf, melihat sesuatu yang baru, menikmati keindahan alam, mengetahui hikayat rakyat setempat, mendapatkan ketenangan.

2. Pariwisata untuk rekreasi (Recreation Tourism)

Pariwisata ini dilakukan untuk pemanfaatan hari-hari libur untuk beristirahat, memulihkan kembali kesegaran jasmani dan rohaninya, dan menyegarkan diri dari keletihan dan kelelahannya. Dapat dilakukan pada tempat yang menjamin tujuan-tujuan rekreasi yang menawarkan kenikmatan yang diperlukan seperti tepi pantai, pegunungan, pusat-pusat peristirahatan dan pusat-pusat kesehatan.

3. Pariwisata untuk kebudayaan (Cultural Tourism)

Jenis ini ditandai oleh adanya rangkaian motivasi, seperti keinginan untuk belajar di pusat-pusat pengajaran dan riset, mempelajari adat-istiadat, 
kelembagaan, dan cara hidup masyarakat yang berbeda-beda, mengunjungi monumen bersejarah, peninggalan masa lalu, pusat-pusat kesenian dan keagamaan, festival seni musik, teater, tarian rakyat dan lain-lain.

4. Pariwisata untuk olahraga (Sports Tourism)

Pariwisata ini dapat dibagi lagi menjadi dua kategori: Big sports events, yaitu peristiwa-peristiwa olahraga besar seperti Olympiade Games, kejuaraan ski dunia, kejuaraan tinju dunia, dan lainlain yang menarik perhatian bagi penonton atau penggemarnya.Sporting tourism of the Practitioners, yaitu pariwisata olahraga bagi mereka yang ingin berlatih dan mempraktekkan sendiri seperti pendakian gunung, olahraga naik kuda, berburu, memancing dan lain-lain.

5. Pariwisata untuk urusan usaha dagang (Business Tourism)

Menurut para ahli teori, perjalanan pariwisata ini adalah bentuk profesional travel atau perjalanan karena ada kaitannya dengan pekerjaan atau jabatan yang tidak memberikan kepada seseorang untuk memilih tujuan maupun waktu perjalanan.

6. Pariwisata untuk berkonvensi (Convention Tourism)

Pariwisata ini banyak diminati oleh negara-negara karena ketika diadakan suatu konvensi atau pertemuan maka akan banyak peserta yang hadir untuk tinggal dalam jangka waktu tertentu dinegara yang mengadakan konvensi. Negara yang sering mengadakan konvensi akan mendirikan bangunanbangunan yang menunjang diadakannya pariwisata konvensi.

\section{Destinasi Pariwisata}

Dalam Undang-undang Republik Indonesia Nomor 10 tahun 2009 tentang kepariwisataan pasal 1 ayat 6 menyebutkan bahwa daerah tujuan wisata yang selanjutnya disebut destinasi pariwisata adalah kawasan geografis yang berada dalam suatu atau lebih wilayah administratif yang di dalamnya terdapat daya tarik wisata, fasilitas umum, fasilitas pariwisata, aksesibilitas, serta masyarakat yang saling terkait dan melengkapi terwujudnya kepariwisataan.

Destinasi merupakan suatu tempat yang dikunjungi dengan waktu yang signifikan selama perjalanan seseorang dibandingkan dengan tempat lain yang dilalui selama perjalanan (seperti daerah transit). Suatu tempat pasti memiliki batas-batas tertentu baik secara aktual maupun hukum. Menurut Ricardson dan Fluker (2004), destinasi pariwisata didefinisikan sebagai "A significant place visited on atrip, with some form of actual of perceived boundary. The basic geographic unit for the production of tourism statistic" yang dalam bahasa Indonesia dapat diarikan sebagai "Sebuah tempat signifikan yang dikunjungi dalam suatu perjalanan dengan beberapa batas aktual. Sebuah unit geografis untuk kepentingan produksi statistic pariwisata".

\section{Pengertian Objek dan Daya Tarik Wisata}

Menurut Happy Merpaung (2002) Objek dan daya tarik adalah: suatu bentukan dan / atau aktivitas dan failitas yang berhubungan, yang dapat menarik minat wisatawan atau pengunjung untuk datang ke suatu daerah atau tempat tertentu. Objek dan daya Tarik wisata sangat erat hubungannya dengan motivasi 
perjalanan, karena wisatawan ingin mengunjungi serta mendapatkan suatu pengalaman tertentu dalam kunjungannya. Bahkan menurut Titing Kartika dkk. (2016), Aktrasi wisata yang menjadi daya tarik bagi wisatawan betah untuk tinggal lebih lama di daerah tujuan wisata serta sarana-sarana penunjang lainnya.

\section{Atraksi}

Dalam dunia kepariwisataan segala sesuatu yang menarik dan bernilai untuk dikunjungi dan dilihat disebut "atraksi" atau lazim juga dinamakan "objek wisata". Atraksi merupakan pusat dari industri pariwisata, menurut pengeritiannya, atraksi dapat menarik minat wisatawan yang ingin mengunjungi. Suatu tempat tujuan primer (primary destination) adalah tempat atau lokasi yang sangat menarik perhatian wisatawan dan merupakan objek pokok dari perjalanan mereka. Biasanya lokasi ini dapat memuaskan kebutuhan atau minat wisatawan selama beberapa hari atau lebih lama. Tempat tujuan sekunder (stopver destination) adalah suatu tempat yang menarik atau perlu dikunjungi ketika sedang menuju ke primary destination. Tempat semacam ini hanya berusaha memuaskan kebutuhan wisatawan selama satu atau dua hari saja.

Ciri-ciri yang menarik wisatawan adalah :

1. Keindahan alam

2. Iklim atau cuaca

3. Kebudayaan

4. Sejarah

5. Ethnicity-sifat kesukaan

6. Accessibility - kemampuan atau kemudahan berjalan ketempat tertentu.

Dari uraian di atas dapat disimpulkan bahwa atraksi atau daya Tarik wisata adalah segala sesuatu yang menarik dan bernilai untuk dikunjungi dan dilihat.

\section{Fasilitas / Amenitas}

Yang dimksud dengan fasilitas menurut Yoeti, (2008) yaitu: semua bentuk fasilitas yang memberikan pelayanan bagi wisatawan untuk segala kebutuhan selama tinggal atau berkunjung pada suatu daerah tujuan wisata, seperti hotel, motel, restoran, bar, café, Shoping center dan souvenir shop. Sarana wisata merupakan kelengkapan daerah tujuan wisata yang diperlukan untuk melayani kebutuhan wisatawan dalam menikmati perjalanan wisatanya.

\footnotetext{
Aksesibilitas

Aksesibilitas mencakup seluruh infrastruktur transportasi yang menghubungkan wisatawan dari, kedaan selama didaerah tujuan wisata, mulai dari darat, laut, sampai udara. Menurut Yoeti. (2008) aksesibilitas adalah semua kemudahan yang diberikan bukan hanya kepada calon wisatawan yang ingin berkunjung, akan tetapi juga kemudahan selama melakukan perjalanan ke daerah tujuan wisata yang dikunjungi.Yang termsuk dalam kelompok ini adalah: airport (bandar udara), seaport (pelabuhan), station (statsiun), highway (jalan raya besar), bridges (jembatan), telecommunication (jaringan komunikasi), atau transportation electric (transportasi listrik) and water supply (persediaan air).
} 
Pada dasarnya semua prasarana yang diberikan kemudahan bagi wisatawan untuk datang berkunjung pada suatu daerh tujuan wisata. Tanpa itu tidak mungkin pariwisata dikembangkan sebagai industri.

Menurut Inskeep (1991) atraksi wisata dibagi menjadi 3 jenis yaitu:

1. Atraksi wisata alamiah yang berdasarkan pada lingkungan yang ada

2. Atraksi wisata budaya yang berdasarkan pada aktivitas manusia

3. Atraksi wisata khusus yang dibuat/dibangun

Melihat jenis-jenis atraksi wisata yang ada di atas, maka Tebing Keraton termasuk kedalam atraksi wisata alamiah yang berdasarkan pada lingkungan yang ada. Karena Tebing Keraton merupaka fenomena alam yang terbentuk alami tanpa campur tangan manusia.

\section{Pemberdayaan Masyarakat}

Peraturan Pemerintah Republik Indonesia No 50 Tahun 2011, Tentang Rencana Induk Pembangunan Kepariwisataan Nasional dalam Pasal 1 menyatakan "Pemberdayaan masyarakat adalah upaya untuk meningkatkan kesadaran, kapasitas, akses, dan peran masyarakat, baik secara individu maupun kelompok, dalam memajukan kualitas hidup, kemandirian, dan kesejahteraan melalui kegiatan kepariwisataan," dan Pasal 28 huruf c yang menyatakan bahwa "Arah kebijakan Pemberdayaan Masyarakat melalui Kepariwisataan meliputi: (a) Pengembangan potensi, kapasitas dan pertisipasi masyarakat melalui Pembangunan Kepariwisataan; (b) optimalisasi pengarusutamaan gender melalui Pembangunan Kepariwisataan; (c) peningkatan potensi dan kapasitas sumber daya lokal melalui pengembangan usaha produktif di bidang pariwisata; (d) penyusunan regulasi dan pemberian isentif untuk mendorong perkembangan industri kecil dan menengah dan Usaha Pariwisata skala usaha mikro, kecil dan menengah yang dikembangkan masyarakat lokal sesuai dengan ketentuan peraturan perundang-undangan; (e) penguatan kemitraan rantai nilai antara usaha di bidang Kepariwisataan; (f) perluasan akses pasar terhadap produk industri kecil dan menengah dan Usaha Pariwisata skala usaha mikro, kecil dan menengah yang dikembangan masyarakat lokal; (g) peningkatan akses dan dukungan permodalan dalam upaya mengembangkan produk industri kecil dan menengah dan Usaha Pariwisata skala usaha mikro, kecil dan menengah yang dikembangkan masyarakat lokal; (h) peningkatan kesadaran dan peran masyarakat serta pemangku kepentingan terkait dalam mewujudkan sapta pesona untuk menciptakan iklim kondusif Kepariwisataan setempat; (i) peningkatan motivasi dan kemampuan masyarakat dalam mengenali dan mencintai bangsa dan tanah air melalui perjalanan wisata nusantara.

Pemberdayaan masyarakat adalah sebuah proses dan tujuan. Sebagai proses, pemberdayaan adalah serangkaian kegiatan untuk memperkuat kekuasaan atau kebudayaan kelompok lemah dalam masyarakat, termasuk individu-individu yang mengalami masalah kemiskinan. Sebagai tujuan, maka pemberdayaan menunjukan keadaan atau hasil yang ingin dicapai oleh sebuah perubahan sosial, yaitu masyarakat yang berdaya, memiliki kekuasaan, tau mempunyai pengetahuan dan kebutuhan hidupnya, baik yang bersifat fisik, ekonomi, maupun sosial seperti kepercayaan diri, mempunyai mata pencaharian, berpartisipasi dalam kegiatan 
sosial, dan mandiri dalam melaksanakan tugas-tugas kehidupannya (Suharto, 2009).

Menurut Simon dalam Harry Hikmat (2001) dalam tulisannya tentang Rethinking Empowerment, definisi pemberdayaan yakni : "Pemberdayaan adalah suatu aktifitas refleksi, suatu proses yang mampu diinisiasikan dan dipertahankan hanya oleh agen atau subyek yang mencari kekuatan atau penentu diri sendiri (self-determination). Sementara proses lainnya hanya dengan memberikan iklim, hubungan, sumber-sumber, dan alat-alat procedural yang melaluinya masyarakat dapat meningkatkan kehidupannya. Pemberdayaan merupakan sistem yang berinteraksi dengan lingkungan sosial dan fisik".

Berdasarkan definisi ini, Harry Hikmat menyimpulkan bahwa pemberdayaan masyarakat bukan upaya pemaksaan kehendak atau proses yang dipaksakan. Lebih utama lagi adalah pendelegasian kekuasaan atau kekuatan yang tidak sesuai dengan potensi masyarakat. Kegiatan pemberdayaan hendaknya menekankan pada prespektif sosial budaya, bukan politik dan ekonomi semata.

Dalam pemberdayaan masyarakat, masyarakatlah yang menjadi aktor dan penentu pembangunan. Dalam kaitan ini, usulan-usulan masyarakat merupakan dasar bagi program nasional. Di sini, masyarakat difasilitasi untuk mengkaji kebutuhan, masalah dan peluang pembanunan dan perkehidupan mereka sendiri. Selain itu mereka juga menemu-kenali solusi yang tepat dan mengakses sumber daya yang diperlukan, baik sumber daya eksternal maupun sumber daya milik masyarakat itu sendiri.

Salah satu strategi yang memungkinkn dalam pemberdayaan masyarakat adalah pengembangan pariwisata berbasis masyarakat yang secara konseptual memiliki ciri-ciri unik serta sejumlah karakter yang oleh Nasikun (2000) dikemukakan sebagai berikut :

1. Pariwisata berbasis masyarakat menemukan rasionalitasnya dalam property dan ciri-ciri unik dan karakter yang lebih unik diorganisasikan dalam skala yang kecil, jenis pariwisata ini pada dasarnya merupakan, secara ekologis aman, dan tidak banyak menimbulkan dampak negative seperti dihasilkan oleh jenis pariwisata konvensional.

2. Pariwisata berbasis komunitas memiliki peluang lebih mampumengembangkan obyek-obyek dan atraksi-atraksi wisata berskala kecil dan oleh karena itu dapat dikelola oleh komunitas-komunitas dan pengusaha-pungusaha local.

3. Berkaitan sangat ert dan sebagai konsekuensi dari keduanya lebih dari paiwisata konvensional, dimana komunitas local melibatkan diri dan menikmati keuntungan perkembangan pariwisata, dan oleh karena itu lebih memberdayakan masyarakat.

Menurut Randy W dan Riant Nugroho (2007) pemberdayaan adalah sebuah "Proses Menjadi" bukan sebuah "Proses Instan". Proses pemberdayaan hendaknya meliputi :

a) Enabling (menciptakan suasana kondusif)

b) Empowering (penguatan kapasitas dan kapabilitas)

c) Protecting (perlindungan dari ketidak adilan)

d) Suporting (bimbingan dan dukungan)

e) Foresting (memelihara kondusifitas) 
Dengan proses pemberdayaan sebagaimana tersebut diatas, pada giliraannya diharapkan akan terwujud kapasitas ketahanan masyarakat secara lebih bermakna dalam mencapai kesejahteraannya, bukan sebaliknya menjebak masyarakat pada suasana penuh ketergantungan. Artinya tujuan pemberdayaan masyarakat harus membuat masyarakat menjadi :

1. Swadiri, mampu mandiri mengurus dirinya sendiri

2. Swadana, mampu membiayai keperluannya sendiri

3. Swakelola, mampu mengelola potensinya sendiri

4. Swasembada, mampu memenuhi kebutuhan sendiri secara berkelanjutan.

Pemberdayaan pada hakikatnya adalah untuk menyiapkan masyarakat agar mereka mampu dan mau secara aktif berpartisipasi dalam setiap program dan kegiatan pembangunan yang bertujuan untuk memperbaiki mutu hidup (kesejahteraan) masyarakat, baik dalam pengertian ekonomi, sosial, fisik, maupun mental. Meskipun partisipasi masyarakat dalam proses pembangunan, adanya kepercayaan dan kesempatandan kesempatan yang diberikan oleh "Pemerintah" kepada masyarakat untuk terlibat secara aktif di dalam proses pembangunan. Berikut ini akan dijelaskan karakteristik dan tipologi partisi masyarakat:

1. Partisipasi Pasif /Manipulatif

- Masyarakat diberitahu apa yang sedang atau telah terjadi.Pengumuman sepihak oleh pelaksana proyek tanpa memperhatikan tanggapan masyarakat.

- Informasi yang dipertukarkan terbatas pada kalangan profesional di luar kelompok sasaran.

2. Partisipasi dengan cara memberikan informasi

- Masyarakat menjawab pertanyaan-pertanyaan penelitian.

- Masyarakat tidak mempunyai kesempatan untuk terlibat dan mempengaruhi proses penelitian.

- Akurasi hasil penelitian tidak dibahas bersama masyarakat.

3. Partisipasi melalui Konsultasi

- Masyarakat berpartisipasi dengan cara berkonsultasi.

- Orang luar mendengarkan, menganalisa masalah dan pemecahannya, dengan memodifikasi tanggapan masyarakat.

- Tidak ada peluang bagi pembuatan keputusan bersama.

- Para profesional tidak berkewajiban mengajukan pandangan masyarakat (sebagai masukan) untuk ditindak-lanjuti.

4. Partisipasi untuk Insentif Materiil

- Masyarakat menyediakan sumberdaya seperti tenaga kerja demi mendapatkan imbalan/upah.

- Masyarakat tidak dilibatkan dalam eksperimen atau proses pembelajarannya.

- Masyarakat tidak mempunyai andil untuk melanjutkan kegiatan-kegiatan pada saat insentif yang disediakan habis.

5. Partisipasi Fungsional

- Masyarakat membentuk kelompok untuk mencapai tujuan proyek.

- Pembentukan kelompok (biasanya) setelah ada keputusan-keputusan utama yang disepakati. 
- Awalnya masyarakat bergantung pada pihak luar, tetapi pada saatnya mampu mandiri.

6. Partisipasi Interaktif

- Masyarakat berperan dalam analisis bersama untuk perencanaan kegiatan dan pembentukan atau penguatan kelembagaan.

- Cenderung melibatkan metodologi interdisipliner yang mencari keragam $\neg$ an perspektif dalam proses belajar yang terstruktur dan sistematik.

- Masyarakat mempunyai peran kontrol atas keputusan-keputusan mereka, sehingga mempunyai andil dalam keseluruhan kegiatan.

7. Partisipasi Mandiri (Self Mobilization)

- Masyarakat mengambil inisiatif secara bebas (tidak dipengaruhi pihak luar) untuk mengubah sistem-sistem atau niali-nilai yang mereka miliki.

- Masyarakat mengembangkan kontak dengan lembaga-lembaga lain untuk mendapatkan bantuan-bantuan teknis dan sumberdaya yang dibutuhkan.

- Masyarakat memegang kendali atas pemanfaatan sumberdaya yang ada.

Pemberdayaan Masyarakat menurut Mardikanto dan Soebianto Poerwoko (2012) adalah tumbuh dan berkembangnya partisipasi masyarakat memberikan indikasi adanya pengakuan (aparat) pemerintah bahwa masyarakat bukanlah sekedar obyek atau penikmat hasil pembangunan, melainkan subyek atau pelaku pembangunan yang memiliki kemampuan dan kemauan yang dapat diandalkan sejak perencanaan, pelaksanaan, pengawasan, dan pemanfaatan hasil-hasil pembangunan. Tentang hal ini, adanya kesempatan yang diberikan, sering merupakan factor pendorong tumbuhnya kemauan, dan kemauan akan sangat menentukan kemampuan.

Syarat tumbuh dan berkembangnya partisipasi masyarakat :

(1) Kesempatan untuk berpartisipasi

Beberapa kesempatan yang dimaksud disini adalah :

a) Kemauan politik dari pengusaha untuk melibatkan masyarakat dalam pembangunan, baik dalam pengambilan keputusan perencanaan, pelaksanaan, monitoring dan evaluasi, pemeliharaan, dan pemanfaatan pembangunan, sejak di tingkat pusat sampai di jajarkan birokrasi yang paling bawah

b) Kesempatan untuk memperoleh informasi pembangunan

c) Kesempatan memanfaatkan dan memobilitasi sumber daya (alam dan manusia) untuk pelaksanaan pembangunan

d) Kesempatan untuk memperoleh dan menggunakan teknologi yang tepat, termasuk peralatan/perlengkapan penunjang

e) Kesempatan untuk berorganisasi, termasuk untuk memperoleh dan menggunakan peraturan, perijinan, dan prosedur keiatan yang akan dilaksanakan

f) Kesempatan mengembangkan kepemimpinan yang mampu menumbuhkan, menggerakan, dan mengembangkan serta memelihara partisipasi masyarakat.

(2) Kemampuan untuk berpartisipasi. Yang dimaksud kemampuan disini adalah: 
a) Kemampuan untuk menemukan dan memahami kesempatan-kesempatan untuk membangun, atau pengetahuan tentang peluang untuk membangun (memperbaiki mutu hidup)

b) Kemampuan untuk melaksanakan pembangunan yang mempengaruhi oleh tingkat pendidikan dan keterampilan yang dimiliki

c) Kemampuan untuk memecahkan masalah yang dihadapi dengan menggunakan sumberdaya dan kesempatan (peluang) lain yang tersdia secara optimal.

(3) Kemauan untuk berpartisipasi

Kemuan untuk berpartisipasi, utamanya ditentukan oleh sikap mental yang dimiliki masyarakat untuk membangun atau memperbaiki kehidupannya, yang menyangkut:

a) Sikap untuk meninggalkan nilai-niai yang menghambat pembangunan

b) Sikat terhadap penguasa atau pelaksana pembangunan pada umumnya

c) Sikapuntuk selalu ingin memperbaiki mutu hidup dan tidak cepat puas diri

d) Sikap kemandirian atau percaya diri atas kemampuannya untuk memperbaiki mutu hidupnya.

Dalam pemberdayaan masyarakat, tentunya terdapat tujuan untuk terciptanya peengembangan masyarakat setempat/lokal. Pengembangan masyarakat lokal adalah proses yang ditunjukan untuk melibatkan kemampuan sosial dn ekonomi bagi masyarakat melalui partisipasi aktif serta inisiatif anggota masyarakat itu sendiri. Anggota masyarakat dipandang bukan sebagai sistem dan yang bermasalah, tetapi sebagai masyarakat kecil yang memiliki potensi, hanya saja potensi itu belum dikembangkan. Pengembangan masyarakat lokal pada dasarnya merupakan proses interaksi antara anggota masyarakat setempat yang difasilitasi oleh lembaga sosial, yang membantu meningkatkan kesadaran dan mengembangkan kemampuan mereka dalam mencapai tujuan-tujuan yang diharapkan.

Sulistiyani (2004) menjelaskan bahwa tujuan yang ingin dicapai dari pemberdayaan masyarakat adalah untuk membentuk individu dan masyarakat menjadi mandiri. Kemandirian tersebut meliputi kemandirian berfikir, bertindak, dan mengendalikan apa yang mereka lakukan. Kemandirian masyarakat merupakan suatu kondisi yang dialami oleh masyarakat yang ditandai dengan kemampuan memikirkan, memutuskan serta melakukan sesuatu yang dipandang tepat demi mencapai pemecahan masalah yang dihadapi dengan mempergunakan daya/kemampuan yang dimiliki.

Dalam suatu pemberdayaan masyarakat dalaam pengembangan pariwisata di perlukan juga pengertia tentang "sadar wisata" sebagai persyaratan utama bagi tumbuh dan berkembangnya kegiatan pariwisata baik di daerah maupun tingkat nasional, serta meningkatkan nilai manfaat pariwisata bagi seluruh masyarakat. Pelaksanaan sadar wisata bertujuan untuk:

a. Meningkatkan pemahaman segenap komponen masyarakat untuk menjadi tuan rumah yang baik dalam mewujudkan iklim yang kondusif bagi tumbuh dan berkembangnya pariwisata serta meningkatkan kesejahteraan masyarakat. 
b. Menggerakan dan menumbuhkan motivasi, kemanapun dan kesemoatan bagi masyarakat sebagai wisatawan untuk mengenali dan mencintai tanah air.

Pendekatan pelaksanaan sadar wisata dilakukan dengan cara informative, persuasive, dan edukatif (Panduan Pelaksanaan Sadar Wisata:03-08). Gerakan masyarakat terhadap sadar wisata yaitu untuk menumbuhkan masyarakat agar siap untuk berperan sebagai tuan rumah (host) dan memahami, mampu serta bersedia untuk mewujudkan SAPTA PESONA di lingkungannya yang meliputi unsurunsur : aman, tertib, bersih, sejuk, indah, ramah dan kenangan.

Sapta Pesona merupakan jabaran konsep SADAR WISATA yang terkait dengan lingkungan dan suasana kondusif yang mampu mendorong tumbuh dan berkembangnya industry pariwisata, melalui perwujudan unsur aman, tertib, bersih, sejuk, indah, ramah, kenangan. Jabaran masing-masing unsur sapta pesona tersebut adalah sebagai berikut:

1) Aman

Suatu kondisi di destinasi pariwisata atau daerah tujuan wisata yang memberikan rasa tenang, bebas dari rasa takut dan kecemasan bagi wisatawan dalam melakukan perjalanan atau kunjungan ke daerah tersebut

2) Tertib

Suatu kondisidan pelayanan di destinasi pariwisata/ daerah tujuan wisata yang mencerminkan sikap disiplin yang tinggi serta kualitas fisik dan layanan yang konsisten dan teratur serta efisien sehingga memberikan rasa nyaman dan kepastian bagi wisatawan dalam melakukan perjalanan atau kunjungan ke daerah tersebut.

3) Bersih

Suatu kondisi lingkungan serta kualitas produk dan pelayanan di destinasi pariwisata/ daerah tujuan wisata mencerminkan keadaan sehat/ hygienis sehingga memberikan rasa nyaman dan senang bagi wisatawan dalam melakukan perjalanan atau keunjungan ke daerah tersebut.

4) Sejuk

Suatu kondisi dan pelayanan di destinasi pariwisata/ daerah tujuan wisata yang mencrminkan keadaan yang sejuk dan teduh yang akan memberikan perasaan nyaman dan betah bagi wisatawan dalam melakukan perjalanan atau kunjungan ke daerah tersebut.

5) Indah

Suatu kondisi danpelayanan di destinasi pariwisata/ daerah tujuan wisata yang mencrminkan keadaan yang indah dan menarik yang akan memberikan rasa kagum dan kesan mendalam bagi wisatawan dalam melakukan perjalanan atau kunjungan ke daerah tersebut, sehinga mewujudkan potensi kunjungan ulang serta mendorong promosi ke pariwisataan yang lebih luas.

6) Ramah

Suatu kondisi dan pelayanan di destinasi pariwisata/ daerah tujuan wisata yang mencerminkan suasana yang akan terbuka dan penerimaan yang tinggi yng akan memberikan perasaan nyaman, perasaan diterima dan betah (seperti rumah sendiri) bagi wisatawan dalam melakukan perjalanan dan kunjungan ke daerah tersebut. 
7) Kenangan

Suatu kondisi dan pelayanan di destinasi pariwisata/ daerah tujuan wisata yang memberikan rasa senang dan kenangan indah yang membekas bgi wisatawan dalam melakukan perjalanan atau kunjungan ke daerah tersebut.

Sejalan dengan perkembangan paradigma pembangunan yang menekan upaya pemberdayaan maysarakat serta orientasi pembangunan yang mengarah pada 3 pilar, yaitu: Pro job (menciptakan lapangan kerja), Pro Poor (menanggulangi dan mengurangi kemiskinan), dan Pro Growth (mendorong pertumbuhan). Maka makna konsep sadar wisata perlu diperdalm agar meningkatkan posisi masyarakat sebagai penerima manfaat yang sebesar-besarnya dari pengembangan kegiatan pariwisata (Panduan Pelaksanaan Sadar Wisata dan Sapta Pesona: 16-25).

\section{Wisatawan}

Wisatawan adalah orang yang melakukan wisata. Sehingga orang-orang yang melakukan rekreasi disebut wisatawan, namun tidak untuk mnetap secara terus menerus dan tidak melakukan bisnis. Kata Wisatawan (Tourist) merujuk kepada orang. Secara umum wisatawan menjadi subset atau bagian dari traveler dan visitor. Untuk dapat disebut sebagai wisatawa, sehingga haruslah seorang traveler, tetapi tidak semua traveler adalah tourist. Traveller memiliki konsep yang lebih luas, yangdapat mengacu kepada orang yang mempunyai beragam peran dalam masyarakat yang melakukan kegiatan rutin ketempt kerja, sekolah dan sebagainya sebagai aktivitas sehari-hari. Orang-orang menurut kategori ini sama sekali tidak dapat dikatakan sebagai tourist (Marpaung dan Bahar, 2000).

\section{KERANGKA PEMIKIRAN}

Penjelasan: Dalam kawasan wisata Tebing Keraton yaitu Kampung Ciharegeum Puncak Desa Ciburial dibutuhkan suatu pemberdayaan masyarakat, dalam upaya memandirikan masyarakat sehingga dapat ikut berkembang beriringan dengan berkembangnya suatu destinasi wisata di daerah tersebut (Tebing Keraton). Penulis melihat dari potensi sumber daya alam dan sumber daya manusia di Kampung Ciharegeum Puncak yang dapat dikembangkan, maksudnya adalah dengan melihat potensi penulis dapat mengetahui pemberdayaan seperti apa yang akan dilakukan di kawasan Tebing Keraton yaitu di Kampung Ciharegeum Puncak. Penulis juga akan meneliti ada atau tidaknya pemberdayaan masyarakat di Kampung Ciharegeum puncak yang meliputi proses, enabling (menciptakan suasana kondusif), empowering (penguatan kapasitas dan kapabilitas), protecting (perlindungan daari ketidak adilan), supporting (bimbingan dan dukungan), foresting (memelihara kondusifitas), yang bertujuan memberikn efek, swadiri (mampu mandiri mengurus dirinya sendiri), swadana (mampu membiayai keperluan sendiri), swakelola (mampu mengelola potensi diri), swasembada (mampu memiliki kebutuhan sendiri secara berkelanjutan). Melalui teknik wawancara, sebar kuisioner pada warga sekitr Kampung Ciharegeum Puncak dan kemudian dilakukan analisis data dengan pengumpulan 
data, reduksi data dan sajian data, sehingga akan di ketahui proses pemberdayaan apa yang sudah ada di kawasan wisata Tebing Keraton yaitu di Kampung Ciharegeum Puncak Desa Ciburial.

\section{METODOLOGI PENELITIAN}

Pada penelitian ini penuli menggunakan penelitian deskriptif, yaitu suatu metode penelitian suatu kelompok manusia, suatu subjek, suatu set kondisi, suatu sistem pemikiran ataupun suatu kelas pariwisata pada masa sekarang. Tujuan penelitian deskriptif adalah untuk membuat deskriptif gambaran atau pelukisan secara sistematis, aktual dan akurat mengenai fakta-fakta, sifat-sifat serta hubungan antar fenomena yang akan diselidiki (Nazir, 2005). Penelitian ini sering disebut noneksperimen, karena pada penelitian ini peneliti tidak melakukan control dan manipulasi vriabel penelitian. Di samping itu, penelitian deskriptif juga merupakan penelitian, dimana pengumpulan data untuk mengetes pertanyaan penelitian atau hipotesis yang berkaitan dengan keadaan dan kejadian sekarang.

\section{Desain Penelitian}

Agar penelitian dapat dilakukan terstrukur denga baik, penelti membuat desain penelitian sebagai berikut:

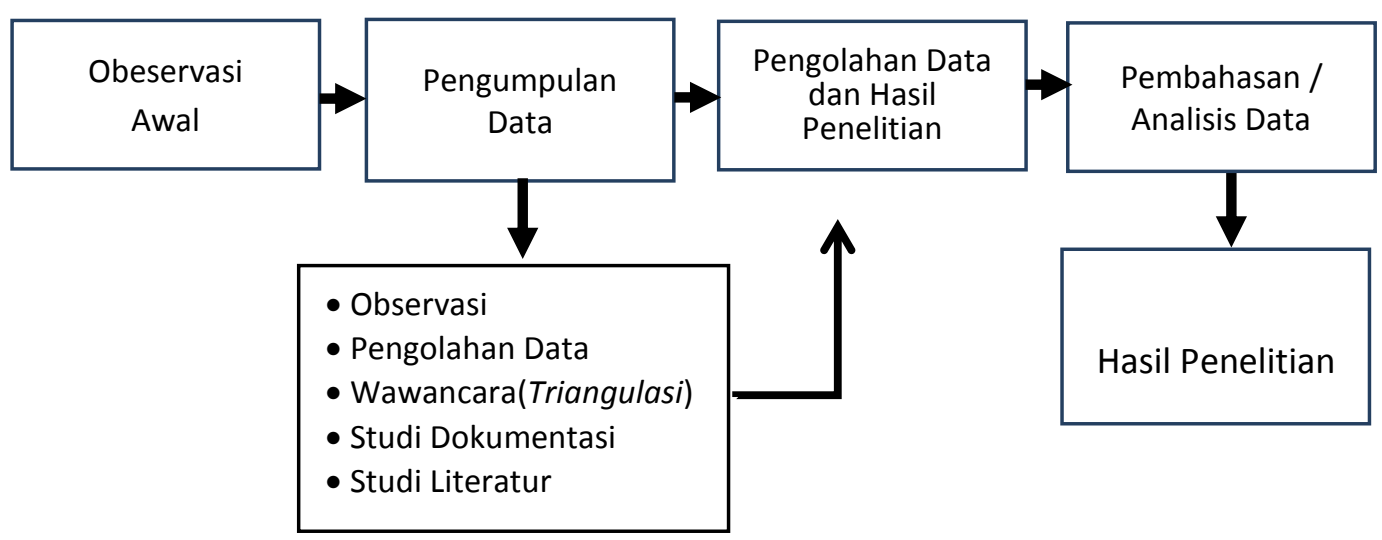

\section{Sampel}

Sampel menurut Sugiyono (2010), adalah bagian dari jumlah dan karakteristik yang dimiliki oleh populasi tersebut. Bila populasi besar, dan penelitian tidak mungkin mempelajari semua yang ada pada populasi, maka kesimpulan dari sampel populasi tersebut dapat diberlakukan.Sampel (key informen) yang diambil dalam penelitian ini yaitu masyarakat Kampung Ciharegem Puncak yang berada di RW 10.

Dalam penelitian kualitatif tidak menggunakan istilah populasi, tetapi Spradley (1980) menamakan objek penelitian sebagai "social situation" atau situasi sosial yang terdiri dari tiga elemen yaitu: tempat (place), pelaku (actor)dan aktivitas (activity) (Sugiyono, 2010). Penentuan sampel dalam penelitian ini menggunakan purposive sampling yaitu metode penetapan sampel dengan pertimbangan tertentu. Pertimbangan tertentu ini adalah menentukan orang yang 
dianggap paling tahu dan dapat memberikan data lebih lengkap dalam mengembangkan sumber daya manusianya. Sehingga memudahkan untuk menjelajahi obyek/situasi sosial yang diteliti.

Di dalam penelitian ini, peneliti sebagai humaninstrument ikut berpartisipasi di lapangan, mencatat apa yang terjadi, melakukan analisis reflektif terhadap berbagai dokumen yang ditemukan di lapangan, dan membuat laporan penelitian secara mendetail. Untuk memperoleh data yang akurat, maka penulis bertindak sebagai instrumen utama (key instrument) dengan cara langsung ke lapangan dan menyatu dengan sumber data.

Adapun penelitian ini mengacu pada data primer dan data sekunder. Data primer diperoleh secara langsung dari objek penelitian yaitu di Tebing Keraton melalui wawancara, observasi dan dokumentasi. Data sekunder diperoleh dari sumber-sumber lain yang menunjang penelitian ini. Sumber-sumber yang dijadikan informan dalam penelitian ini adalah sebagai berikut:

\section{Tabel 1}

\section{Sumber Data/Informan Kunci}

\begin{tabular}{|c|c|c|}
\hline No & $\begin{array}{c}\text { Sumber Data/ } \\
\text { Informan Kunci }\end{array}$ & Data Terkait \\
\hline 1 & Kepala Desa Ciburial & $\begin{aligned} & \text { Tentang : } \\
& \text { - } \text { Pemberdayaan Masyarakat } \\
& \text { - } \text { Rencana Infrastruktur } \\
& \text { - } \text { Sumber Mata Pencaharian Masyarakat } \\
& \text { - } \text { Pelatihan Dalam Konteks Sadar Wisata } \\
&\end{aligned}$ \\
\hline 2 & Ketua RW 9 dan RW 10 & $\begin{aligned} \text { Tentang : } & \\
\text { - } & \text { Pemberdayaan Masyarakat } \\
\text { - } & \text { Rencana Infrastruktur } \\
\text { - } & \text { Sumber Mata Pencaharian Masyarakat } \\
\text { - } & \text { Pelatihan Dalam Konteks Sadar Wisata } \\
\text { - } & \text { Dampak Hadirnya Destinasi Wisata Bagi } \\
& \text { Masyarakat }\end{aligned}$ \\
\hline 3 & $\begin{array}{l}\text { Dinas Pariwisata dan } \\
\text { Kebudayaan Provinsi } \\
\text { Jawa Barat }\end{array}$ & $\begin{aligned} \text { Tentang : } & \\
- & \text { Rencana Strategi Infrastruktur } \\
- & \text { Konsep Pemberdayaan Masyarakat } \\
- & \text { Rencana Pengembangan Strategis } \\
& \text { Destinasi Wisata }\end{aligned}$ \\
\hline 4 & $\begin{array}{l}\text { Taman Hutan Raya Ir. H. } \\
\text { Djuanda }\end{array}$ & $\begin{aligned} \text { Tentang : } & \\
\text { - } & \text { Pemberdayaan Masyarakat } \\
\text { - } & \text { Rencana Infrastruktur } \\
\text { - } & \text { Pelatihan Dalam Konteks Sadar Wisata } \\
\text { - } & \text { Manajemen Pengelolaan Tebing Keraton }\end{aligned}$ \\
\hline 5 & Tokoh Masyarakat & $\begin{aligned} \text { Tentang: } & \\
- & \text { Pemberdayaan Masyarakat } \\
\text { - } & \text { Rencana Infrastruktur } \\
- & \text { Sumber Mata Pencaharian Masyarakat }\end{aligned}$ \\
\hline
\end{tabular}




\begin{tabular}{|l|l|l|}
\hline & - & Pelatihan Dalam Konteks Sadar Wisata \\
& - & Dampak Hadirnya Destinasi Wisata Bagi \\
& Masyarakat \\
\hline
\end{tabular}

\section{Jenis dan Sumber Data}

1) Data Primer

Sumber primer adalah sumber data yang langsung memberikan data pada pengumpulan data (Sugiyono, 2008). Data primer adalah data yang didapat dari sumber pertama baik dari individu ataupun perseorangan, seperti dari wawancara atau pengisian kuisioner yang dilakukan peneliti (Umar, 2005). Adapun data primer yang diperoleh dalam penelitian ini adalah data mengenai jawaban responden atas wawancara tertutup guna mengetahui data yang dibutuhkan mengenai potensi sumber daya alam dan potensi masyarakat Kampung Ciharegem Puncak serta sektor usaha yang sudah ada.

2) Data Sekunder

Sumber sekunder merupaakan sumber yang tidak langsung memberikan data kepada pengumpul data, misalnya lewat orang lain atau lewat dokumen (Sugiyono, 2008). Data tersebut merupakan data yang diperoleh scara tidak langsung dan sudah diolah oleh pihak-pihak lain. Dalam penelitian ini, data sekunder diperoleh dari pihak Kantor Desa Ciburial, pihak TAHURA (Taman Hutan Raya) Ir.H.Djuanda, tokoh masyarakat Kampung Ciharegem Puncak.

\section{Teknik Pengumpulan Data}

Teknik pengumpulan data dalam penelitian ini adalah:

a) Observasi Lapangan

Observasi Lapangan yaitu mengunjungi langsung lokasi penelitian dan mengumpulkan data-data yang relevan dengan judul penelitian yaitu pemberdayaan masyarakat di destinasi wisata Tebing Keraton Kampung Ciharegem Puncak Desa Ciburial.

b) Wawancara

Wawancara digunakan sebagai pengumpulan data, apabila peneliti ingin melakukan studi pendahuluan untuk menemukan permasalahan yang harus diteliti dan juga apabila penliti ingin mengetahui hal-hal dari responden yang lebih mendalam (Sugiyono, 2012). Dalam hal yang menjadi narasumber Kepala Desa Ciburial, Ketua RT 10, TAHURA Ir. H. Djuanda selaku pengelola Tebing Keraton, Tokoh Masyarakat Kampung Ciharegem Puncak, Ketua RW 10, dan Dinas Pariwisata dan Kebudayaan Provinsi Jawa Barat.

c) Dokumentasi

Menurut Sugiyono (20012), dokumentasi yaitu mengumpulkan dokumen baik yang berbentuk tulisan, gambar, mupun karya. Dokumen tulisan yaitu sejarah kehidupan, biografi, peraturan kebijakan, dan lain-lain. Dokumen yang bergambar yaitu foto, sketsa, gambar hidup. Dokumen berbentuk karya misalnya karya seni berupa gambar, ptung, film dan lain-lain. 


\section{Teknik Pengolahan Data}

Langkah terakhir setelah melakukan penelitian yaitu pengolahan dan analisis data. Penelitian ini bersifat deskriptif yang merupakan proses penggambaran daerah penelitian. Dalam penelitian mengenai pemberdayaan masyarakat di Destinasi Wisata Tebing Keraton Kampung Ciharegem Puncak. Pengolahan data ini dilakukan dengan 4 (empat) tahap yaitu sebagai berikut:

a. Pengumpulan Data (Field Note)

Peneliti melakukan pengumpulan data dari hasil observasi dan interview dilapangan, Dengan melakukan wawancara.

b. Reduksi Data

Data yang diperoleh penulis kemudian dirangkum, lalu dipilih hal-hal yang pokok, memfokuskan pada hal-hal yang penting, dicari tema dan polanya sesuai dengan yang penulis teliti yaitu Pemberdayaan Masyarakat di Destinasi Wisata Tebing Keraton Kampung Ciharegem Puncak Desa Ciburial. Dengan demikian data yang telah direduksi akan diberikan gambaran yang jelas dan mempermudah peneliti untuk melakukan pengumpulan data selanjutnya bila perlu.

c. Sajian Data

Peneliti menyusun sekumpulan informasi yang memberikan kemungkinan adanya penarikan kesimpulan dan pengambilan tindakan. Dalam hal ini, sajian yang diperoleh dari pengolahan data dan hasilnya akan di deskripsikan.

d. Kesimpulan/verifikasi data

Dalam penarikan kesimpulan ini didasarkan pada reduksi data dan sajian data yang merupakan jawaban atas masalah yang diangkat dalam penelitian, lalu keluarlah kesimpulan.

\section{HASIL DAN PEMBAHASAN}

\section{A. Kondisi}

Kampung Ciharegem Puncak yang berada dikawasan Desa Ciburial memiliki 2 (dua) Rukun Warga (RW), yaitu RW 09 dan RW 10.Udara yang sejuk dan susana perkampungan yang bersih membuat semua orang yang berkunjung ke kampung tersebut merasa nyaman. Masyarakat Kampung Ciharegem Puncak sebagian besar sudah berpikir modern dan sadar lingkungan, hal ini dapat terlihat dari suasana kampung yang bersih, tertib, dan teratur.

Berdasarkan Laporan Penyelenggaraan Pemerintahan Desa Ciburial Akhir Tahun 2005, kampung Ciharegem Puncak memiliki kondisi alam yang menarik. Letak geografisnya yang berada di ujung Desa Ciburial yang merupakan kawasan desa yang burbukit dengan variasi kemiringin antara 0,8\%, 8,15\% hingga $40 \%$ (Sumber: membuat kontur tanah di kampung ciharegem puncak lebih landai dan berbukit-bukit. Selain itu kampung ciharegem puncak juga bersebelahan dengan kawasan konservasi Taman Hutan Raya Ir. H. Djuanda, sehingga dari ketinggian Kampung Ciharegem Puncak yang berada di $+/-1200 \mathrm{~m}$ di atas permukaan laut membuat kampung tersebut menyajikan pemandangan hamparan pepohonan 
yang indah. Udaranya yang sejuk,asri, dan alami juga menambah daya tarik di Kampung Ciharegem Puncak.

Kondisi alam yang ada di Kampung Ciharegem Puncak menjadi daya tarik tersendiri untuk menarik wisatawan berkunjung. Kepopuleran kampong ini semakin meningkat di awal tahun 2014. Berdasarkan hasil wawancara dengan tokoh masyarakat di sana, Dede Kurnia (Ketua RW 10) dan Asep (Warga RW10), mereka menyatakan bahwa kepopuleran kampung Ciharegem puncak berawal dari seorang pengguna dunia maya yang mengunggah foto hamparan pepohonan yang diambil dari atas tebing. Kini, kawasan tersebut dikenal dengan nama Tebing Keraton.

Selain itu, menurut Kepala Dinas Bidang Kepariwisataan Ani Ismairini, "kondisi tebing keraton dapat dijadikan sebagai tempat pengamatan burung raptor migran dunia, mengingat kawasan ini juga dihinggapi burung-burung dunia yang melintas untuk berimigrasi antar benua." Ini menjadi daya tarik tersendiri, selain keindahan alamnya.

Berdasarkan hasil analisis peneliti, kondisi dikawasan tersebut belum ditunjang infrasturktur yang baik, terutama kondisi jalan menuju tebing keraton yang berbukit dan masih berbatu di beberapa titik. Juga, tidak adanya ramburambu di sepanjang jalan menuju lokasi sedangkan jalanan disana sangat berliku dan terdapat jurang disisinya sehingga sangat berbahaya untuk pengunjung yang belum mengetahui medan.

Selain itu, tidak ada transportasi umum yang melewati kawasan tersebut sehingga wisatawan yang ingin datang kesana harus menggunakan kendaraan pribadi. Pengunjung yang ingin datang kesana juga direpotkan dengan adanya aturan tidak diperbolehkannya kendaraan beroda 4 untuk naik kekawasan Tebing Keraton. Para wisatawan yang datang menggunakan mobil hanya diperbolehkan masuk hingga kawasan Warung Bandrek tepatnya di kawasan RW 09. Bagi yang datang mennggunakan mobil mereka diberi tiga pilihan. Pertama, tetap naik mobil dengan mengeluarkan tarif tambahan yang tidak berpatok, kedua berjalan kaki sejauh 2 kilometer dengan jalan yang menanjak atau pilihan ketiga menggunakan ojek yang disediakan warga dengan tarif yang tidak pasti.

Jika dilihat dari kondisi yang ada, maka hal itu belum mendukung aksesibilitas sebagaimana pendapat Yoeti (2008) yang menyatakan bahwa, aksesibilitas adalah semua kemudahan yang diberikan bukan hanya kepada calon wisatawan yang ingin berkunjung, akan tetapi juga kemudahan selama melakukan perjalanan ke daerah tujuan wisata yang dikunjungi.

\section{B. Potensi}

Kegiatan ekonomi di Kampung Ciharegem Puncak selama ini masih di dominasi oleh sektor pariwisata, sektor pertanian dan peternakan. Namun, dari pesatnya kepariwisataan dan pertanian di kampung Ciharegem Puncak belum seutuhnya membuahkan hasil optimal bagi kehidupan masyarakat di sekitarnya. Karena, umumnya masih rendahnya pengetahuan SDM (Sumber Daya Manusia) dan kurangnya akses ke sumber permodalan. Sebagian besar mata pencaharian masyarakat di kampung tersebut sebagai pedagang, meskipun potensi dari sektor pertanian dan peternakan sangatlah tinggi namun saat ini sektor tersebut hanyalah 
dijadikan kegiatan ekonomi pendukung. Hal ini disebabkan karena banyaknya lahan di Kampung Ciharegem Puncak yang sudah beralih kepemilikan.

Dari hasil wawancara peneliti dengan Kepala Desa Ciburial, berikut ini adalah potensi di Kampung Ciharegem Puncak :

Tabel 2

Potensi Kampung Ciharegem Puncak

\begin{tabular}{|l|l|l|}
\hline No & Jenis Potensi & Keterangan \\
\hline 1 & Pertanian & $\begin{array}{l}\text { Kentang, kubis, bawang merah, wortel, } \\
\text { kemangi terong, mentimun, jahe, } \\
\text { lengkuas, mengkudu dan lainnya }\end{array}$ \\
\hline 2 & Peternakan & Sapi, kambing, madu \\
\hline 3 & Kerajinan Industri Kecil & Makanan, anyaman, ukiran kayu \\
\hline 4 & Pariwisata & Tebing Keraton \\
\hline
\end{tabular}

Sumber: Data Pemerintah Desa Ciburial Tahun 2015

Sedangkan jika dilihat dari potensi Tebing Keraton, berdasarkan data sekunder dari profil data desa Ciburial pada tahun 2016, rata-rata pengunjung (Agustus-Desember) pada tahun 2014 sebanyak 11.750 perbulan, rata-rata pengunjung (Januari-Desember) pada tahun 2015 sebanyak 12.250 perbulan dan rata-rata pengunjung (Januari-Mei) pada tahun 2016 sebanyak 11.978 perbulan, seperti terlihat dalam tabel berikut ini.

Tabel 3

Data Kunjungan Tebing Keraton

2016

\begin{tabular}{|l|l|l|l|l|}
\hline \multirow{2}{*}{ NO } & \multirow{2}{*}{ BULAN } & TAHUN & $\mathbf{2 0 1 6}$ \\
\cline { 3 - 6 } & & $\mathbf{2 0 1 4}$ & $\mathbf{2 0 1 5}$ & 16.650 \\
\hline 1 & Januari & - & 11.456 & 11.910 \\
\hline 2 & Februari & - & 9.798 & 9.314 \\
\hline 3 & Maret & - & 9.240 & 7.428 \\
\hline 4 & April & - & 8.617 & 14.588 \\
\hline 5 & Mei & - & 15.938 & - \\
\hline 6 & Juni & - & 7.674 & - \\
\hline 7 & Juli & - & 18.019 & - \\
\hline 8 & Agustus & 24.997 & 19.115 & - \\
\hline 9 & September & 15.252 & 11.056 & - \\
\hline 10 & Oktober & 7.162 & Renovasi & - \\
\hline 11 & November & 4.697 & 8.611 & - \\
\hline 12 & Desember & 6.640 & 15.229 & \\
\hline & & & & \\
\hline
\end{tabular}




\begin{tabular}{|l|l|l|l|}
\hline TOTAL & 58.748 & 134.753 & 59.890 \\
\hline
\end{tabular}

Sumber : Data Kunjungan Tebing Keraton

Dari data kunjungan Tebing Keraton diatas dapat dilihat bahwa kunjungan cenderung stabil atau tidak pernah mengalami penurunan secara signifikan, ini dapat menunjukan bahwa tebing keraton memiliki potensi yang tinggi sebagai destinasi wisata. Selain itu, kawasan ini dapat dijadikan kawasan wisata minat khusus untuk education, research, \& sport, pendapat peneliti tersebut didukung oleh Ani Ismairini (Kepala Bidang Kepariwisataan Dinas Pariwisata dan Kebudayaan, Provinsi Jawa Barat), menurutnya, "kedepannya daerah ini dapat dijadikan tempat education, research, sport, dan tourism, namun hingga kini belum ada perencanaan resmi dari Pemerintah Provinsi." Meskipun kondisi jalan yang belum sepenuhnya baik dan rambu-rambu jalan yang belum tersedia, peneliti melihat bahwa hal ini tidak mempengaruhi minat wisatawan.

\section{Pemberdayaan Masyarakat Terhadap Kegiatan Pariwisata di Destinasi Wisata Tebing Keraton}

Masyarakat di Kampung Ciharegem Puncak memanfaatkan fenomena hadirnya destinasi wisata baru ini sebagai lahan mata pencaharian baru yang dimanfaatkan dengan berdagang, pemanfaatan lahan parkir,dan ojek. Tetapi suasana disana masih belum mencerminkan sebuah kawasan wisata yang terkonsep.

Jika dilihat dari aspek dimensi pemberdayaan masyarakat, terdapat 5 proses dalam permberdayaan masyarakat yang meliputi :

a. Enabling (menciptakan suasana kondusif)

Keberadaan tebing keraton banyak membawa dampak positif bagi perekonomian masyarakat di Kampung Ciharegem Puncak. Dari hasil wawancara peneliti dengan Ketua RW10 didapatkan bahwa hasil dari penjualan tiket parkir di Tebing Keraton dapat dirasakan langsung manfaatnya oleh masyarakat sekitar, contohnya adalah perbaikan jalan setapak dikawasan perumahan warga yang tidak lagi menggunakan dana suwadaya warga, bantuan bagi orang lanjut usia yang sudah tidak dapat bekerja, dana untuk UKM Masjid dan lain sebagainya. Namun dari hasil pengamatan peneliti manfaat dari hasil parkir Tebing Keraton ini hanya di rasakan oleh warga RW10, hal inilah yang sempat menimbulakan terjadinya perselisihan paham dalam pengelolaan lahan parkir antara warga RW10 dan RW09, sehingga melibatkan tokoh masyarakat dan aparat keamanan untuk menyelesaikan perselisihan tersebut (Hasil wawancara dengan Kepala Desa Ciburial). Berdasarkan analisis peneliti ini menunjukan bahwa, di Kampung Ciharegem Puncak belum ada konsep yang terpadu dalam menciptakan susasana kondusif sebagai syarat dalam proses pemberdayaan masyarakat.

b. Empowering (penguatan kapasitas dan kapabilitas)

Dari hasil penelitian di Tebing Keraton Kampung Ciharegem Puncak, belum terlihat kapasitas dan kapabilitas masyarakat dalam mengelola lingkungan 
wisata, hal ini ditunjukan dengan area perdagangan yang masih belum tertata dengan baik, cara pelayanan yang masih sangat traditional, dan pengelolaan parkir yang masih terlihat semeraut. Hasil analisis peneliti, ini menunjukan bahwa kapabilitas masyarakat yang ada masih kurang dan belum ada konsep pemberdayaan masyarakat yang diupayakan pemerintah dalam peningkatan kapabilitas masyarakat yang ada untuk mendukung Destinasi wisata. Seharusnya menurut Randy W dan Riant Nugroho (2007) pemberdayaan masyarakat pada hakikatnya adalah untuk menyiapkan masyarakat agar mereka mampu dan mau secara aktif berpartisipasi dalam setiap program dan kegiatan pembangunan yang bertujuan untuk memperbaiki mutu hidup (kesejahteraan) masyarakat, baik dalam pengertian ekonomi, sosial, fisik, maupun mental.

c. Protecting (Perlindungan dari ketidak adilan)

Jika dilihat dari usaha-usaha yang ada dilingkungan kawasan wisata, didominasi oleh penduduk sekitar, namun demikian beberapa lahan sudah dimiliki oleh pihak-pihak luar, sehingga hasil analisis peneliti, lahan yang telah di jual kepihak luar dapat dijadikan usaha pendukung kawasan wisata, sehingga hal ini dapat menimbulkan persaingan antara penduduk lokal dan pendatang. Jika hal ini tidak di proteksi dengan baik, maka pemberdayaan masyarakat yang ada di sekitarnya bisa gagal, karena masyarakat disana hanya memiliki modal yang terbatas. Ini, menunjukan tidak adanya perlindungan dari pemerintah ataupun pejabat desa untuk mendukung kegiatan ekonomi di kawasan wisata.

d. Supporting (Dukungan dan bimbingan)

Berdasarkan hasil penelitian telah dilakukan pembinaan seperti diungkapkan oleh Imam Sutanto (Kepala Desa Ciburial) dan Hasan Kuswara ( Kepala Seksi Pemanfaatan di Taman Hutan Raya Ir.H.Djuanda) pemerintah telah melakukan bimbingan dan dukungan dalam bentuk penyuluhan dan forum musyawarah tentang kepariwisataan yang di bimbing oleh DISBUDAR. Selain itu masyarakat juga di berdayakan dalam kegiatan budi daya madu, budi daya anggrek, pelatihan pembuatan kerajinan tangan, pelatihan penangkaran burung dan lainsebagainya. Hasil analisis peneliti, bentuk penyuluhan telah dilakukan dengan baik oleh DISBUDPAR dan TAHURA namun bimbingan dan dukungan tersebut belum dilakukan secara berkesinambungan.

e. Foresting (Memelihara Kondusifitas)

Berdasarkan hasil penelitian menunjukan sudah ada upaya pemeliharaan kondusifitas yang ditunjukan dengan adanya musyawarah di kampung Ciharegem puncak. Ini, menunjukan bahwa dimensi foresting telah dilakukan dengan baik dalam mendukung pemberdayaan masyarakat di kampung Ciharegem puncak.

\section{SIMPULAN DAN SARAN}

Pemberdayaan Masayarakat di Destinasi Wisata Kampung Ciharegem Puncak, Desa Ciburial diharapkan menjadi salah satu andalan dan mampu meningkatkan kualitas hidup masyarakat di sana. Berdasarkan hasil penelitian kualitatif mengenai Pemberdayaan Masyarakat di Destinasi Wisata Tebing 
Keraton, Kampung Ciharegem Puncak Desa Ciburial yang dilakukan melaui observasi, wawancara, dan dokumentasi, maka didapat kesimpulan sebagai berikut :

1. Potensi dan Kondisi : Tebing keraton memiliki kondisi alam yang mendukung sebagai destinasi wisata, dan memiliki potensi yang baik sebagai kawasan wisata minat khusus seperti education, research, sport and tourism. Namun infrastruktur disana belum memadai dan belum belum memiliki rambu-rambu lalulintas sehingga dapat menibulkan bahaya.

2. Pemberdayaan Masyarakat : Secara keseluruhan dapat disimpulakan, dimensei didalam memberdayakan masyarakat dari prespektif Randy W dan Riant Nugroho (2007) bahwa :

1) Enabling

Di kampung Ciharegem Puncak belum ada konsep yang terpadu dalam menciptakan susasana kondusif sebagai syarat dalam proses pemberdayaan masyarakat.

2) Empowering

Belum ada konsep pemberdayaan masyarakat dalam peningkatan kapabilitas masyarakat yang ada untuk mendukung tujuan wisata.

3) Protecting

Karena saat ini belum ada persaingan sehingga bentuk proteksi belum terlihat dengan jalas, namun sudah ada regulasi dari pemerintah untuk pembangunan yang diatur dalam Peraturan Daerah Provinsi Jawa Barat Nomor: 01 Tahun 2008.

4) Suporting

Bentuk penyuluhan telah dilakukan dengan baik oleh DISBUDPAR dan TAHURA namun bimbingan dan dukungan tersebut belum dilakukan secara berkesinambungan.

5) Foresting

Berdasarkan hasil penelitian menunjukan sudah ada upaya pemeliharaan kondusifitas yang ditunjukan dengan adanya musyawarah di Kampung Ciharegem Puncak. Ini menunjukan bahwa dimensi foresting telah dilakukan dengan baik dalam mendukung pemberdayaan masyarakat di kampung Ciharegem puncak

Berdasarkan hasil pembahasan sebelumnya dan hasil kesimpulan penelitian, maka peneliti mengajukan saran-saran akademis yang bersifat untuk menambah, memperkuat dan memperkaya khasanah penelitian terkait dalam pemberdayaan masyrakat :

1. Perbaikan infrastruktur perlu menjadi rencana prioriatas dari rencana strategis pemerintah, karena saat ini sudah banyak wisatawan yang berkunjung ke Tebing Keraton.

2. Didalam melakukan pemberdayaan masyarakat yang efektif, maka tokoh masyarakat khususnya pemerintah perlu menciptakan dan memelihara kondusifitas masyarakat yang dilakukan secara rutin. Dan, pemerintah juga perlu membuat proteksi dalam mendukung usaha kecil masyarakat disekitarnya, meningkatkan kapabilitas masyarakat dalam mengelola lingkungan kawasan wisata sekitarnya. Pemerintah juga perlu melakukan 
penyuluhan-penyuluhan sehingga masyarakat di Kampung Ciharegem Puncak dapat menjadi masyarakat yang sadar wisata.

\section{DAFTAR PUSTAKA}

Data Pemerintah Desa Ciburial 2015 (Potensi Kampung Ciharegem Puncak)

Disparbud Provinsi Jawa Barat. Panduan Pelaksanaan Sadar Wisata. Bandung: Disparbud Prov. Jawa Barat

Hikmat, Harry. 2001. Strategi Pemberdayaan Masyarakat, Bandung: Humaniora Utama Press

Husein Umar. 2005. Metode Penelitian. Jakarta: Salemba Empat

Inskeep Edward. 1991. Tourism Planning An Integrated and Sustainable Development Approach. New York: Van Nostrand Reinhold

Laporan Penyelenggaraan Pemerintahan Desa Ciburial Akhir Tahun 2005

Marpaung, Happy. 2002. Pengetahuan Kepariwisataan. Bandung: Alfabeta

Marpaung, Happy dan Bahar, Herman. 2000. Pengantar Pariwisata. Bandung:Alfabeta

Nasikun. 2000. Sistem Sosial Indonesia. Jakarta: Raja Grafindo Persada

Nazir, M. 2005. Metode Penelitian. Bogor: Ghalia Indonesia

Nyoman S. Pendit. 2006.Ilmu Pariwisata (Sebuah Pengantar Perdana). Jakarta: PT Pradnya Pramita

Yoeti, Oka A. 2008. Perencanaan dan Pengembangan Pariwisata. Jakarta: PT Pradnya Pramita

Peraturan Pemerintah Republik Indonesia No 50 Tahun 2011 Tentang Rencana Induk Pembangunan Pariwisata Nasional Tahun 2010-2025

Richardson, I John \& Martin Fluker. 2004. Understanding and Managing Tourism. Australia: Pearson Education Australia

Spillane, James J. 1987. Ekonomi Pariwisata, Sejarah dan Prospeknya. Kanisius

Sugiyono. 2008. Metode Penelitian Kuantitatif Kualitatif dan $R \quad \& \quad D$. Bandung:Alfabeta

2010. Metode Penelitian Kuantitatif Kualitatif dan $R \& D$. Bandung:Alfabeta

----------. 2012. Metode Penelitian Kuantitatif Kualitatif dan $R \quad \& \quad D$. Bandung:Alfabeta

Suharto, Edi. 2009. Membangun Masyarakat Memberdayakan Rakyat Kajian Strategis Pembangunan Kesejahteraan Sosial. Bandung: Rafika ADITAMA

Sulistiyani, A.T. 2004. Kemitraan dan Model-Model Pemberdayaam. Jogjakarta:Gava Media

Titing Kartika, Nurul Rochmah Pramadika \& Apay Safari. Pengaruh Bauran Pemasaran Terhadap Keputusan Berkunjung Wisatawan Di Lawangwangi Creative Space- Dago Giri Bandung. Jurnal Sains Terapan Pariwisata (2016) Vol. 1 No. 1 
Undang Undang Republik Indonesia No.10 Tahun 2009 tentang Kepariwisataan

Wrihatnolo, R dan Nugroho Riant. 2007. Manajemen Pemberdayaan: Sebuah Pengentar dan Panduan untuk Pemberdayaan Masyarakat. Jakarta:Gramedia/Elexmedia Komputindo.

WTO. 1998. Guide for Local Authorities on Developing Sustaiable Tourism. Pubished by the World Tourism Organization

\section{Media Online :}

Profile Desa Ciburial. 2016. [Online]. Tersedia: https://ciburial.desa.id/. [9 September 2016] 